\title{
Photocatalytic Active Coatings for Lignin Degradation in a Continuous Packed Bed Reactor
}

\author{
Colin Awungacha Lekelefac, ${ }^{1}$ Johannes Hild, ${ }^{1}$ \\ Peter Czermak, ${ }^{1,2,3}$ and Michael Herrenbauer ${ }^{4}$ \\ ${ }^{1}$ Institute of Bioprocess Engineering and Pharmaceutical Technology, University of Applied Sciences Mittelhessen, \\ 35390 Giessen, Germany \\ ${ }^{2}$ Department of Chemical Engineering, Faculty of Engineering, Kansas State University, Manhattan, KS 66506, USA \\ ${ }^{3}$ Faculty of Biology and Chemistry, Justus Liebig University, Giessen, Germany \\ ${ }^{4}$ Faculty of Biology and Chemistry, Justus Liebig University, 35392 Giessen, Germany
}

Correspondence should be addressed to Peter Czermak; peter.czermak@kmub.thm.de

Received 9 December 2013; Revised 23 February 2014; Accepted 24 February 2014; Published 1 April 2014

Academic Editor: Vincenzo Augugliaro

Copyright (C) 2014 Colin Awungacha Lekelefac et al. This is an open access article distributed under the Creative Commons Attribution License, which permits unrestricted use, distribution, and reproduction in any medium, provided the original work is properly cited.

\begin{abstract}
The synthesis of immobilized catalyst on porous glass support material via the sol-gel route is reported. $\mathrm{TiO}_{2}-\mathrm{P} 25-\mathrm{SiO}{ }_{2}+\mathrm{Pt}$, TiO $\mathrm{P} 25-\mathrm{SiO}_{2}, \mathrm{TiOSO}_{4} 30.6 \mathrm{wt} \%$, and $\mathrm{ZnO}+\mathrm{TiO}_{2}-\mathrm{P} 25-\mathrm{SiO}_{2}$ catalysts were synthesized and a comparative study is done regarding morphology of coatings, degradation rates, reaction rates, dissolved carbon (DC), formation of peaks, and fluorescence of products formed from the photocatalytic degradation of lignin sulfonate obtained from a local paper plant. Through simultaneous reactionextraction pathways applying dialysis filtration and highly porous polystyrene divinylbenzene adsorbent resin (HR-P) for solid phase extraction (SPE), an attempt has been made to isolate smaller molecules produced from photocatalytic degradation. Moreover relatively high lignin sulfonate $(0.5 \mathrm{~g} / \mathrm{L})$ concentrations are used in the reactions. UV-Vis spectroscopy revealed a faster reduction in the concentration values for the aliphatic moiety compared to the aromatic moiety. Peaks were observed by both fluorescence spectroscopy and HPLC suggesting the production of new substances and fluorophores.
\end{abstract}

\section{Introduction}

There is growing awareness of the rapid depletion of fossil materials which makes it imperative to think of the development of commercial viable "green products" based on alternatives for fossil fuels. Commercial lignin is byproduct of the pulp and paper industries, wood hydrolysis industries, and pretreatment technologies to obtain cellulosic ethanol and biodiesel. More than 70 million tons of various types of lignin are produced as waste material by the paper industry yearly [1]. Coupled to that, lignin and its degradation products cannot be completely decomposed by sludge processes and are the source of chemical oxygen demand (COD) of waste water from pulp and paper mills [2]. Lignin is primarily a structural material to add strength and rigidity to cell walls and constitutes between $15 \mathrm{wt} \%$ and $40 \mathrm{wt} \%$ of the dry matter of woody plants. After cellulose, it is the most abundant renewable carbon source on earth. Lignin can be available through various sources and biomass transformation technologies [3].

Photocatalysis, belonging to the so-called advanced oxidation processes (AOPs) [4], is a potential new transformation technology for lignin to value added products, for example, phenol, benzene, toluene, and xylene [5]. One of such a transforming method is the heterogeneous procedure in which a photocatalytically active layer is immobilized on a support material. In such a system both adsorption and photocatalysis take place and major advantages such as the reuse of catalyst; minimization of catalyst leaching or resistance to extreme physical and chemical conditions is exploited. Most publications treating lignin photocatalysis describe suspension systems [6] with the disadvantage that catalyst particles have to be recovered after reaction through downstream processes such as ultrafiltration which bring 


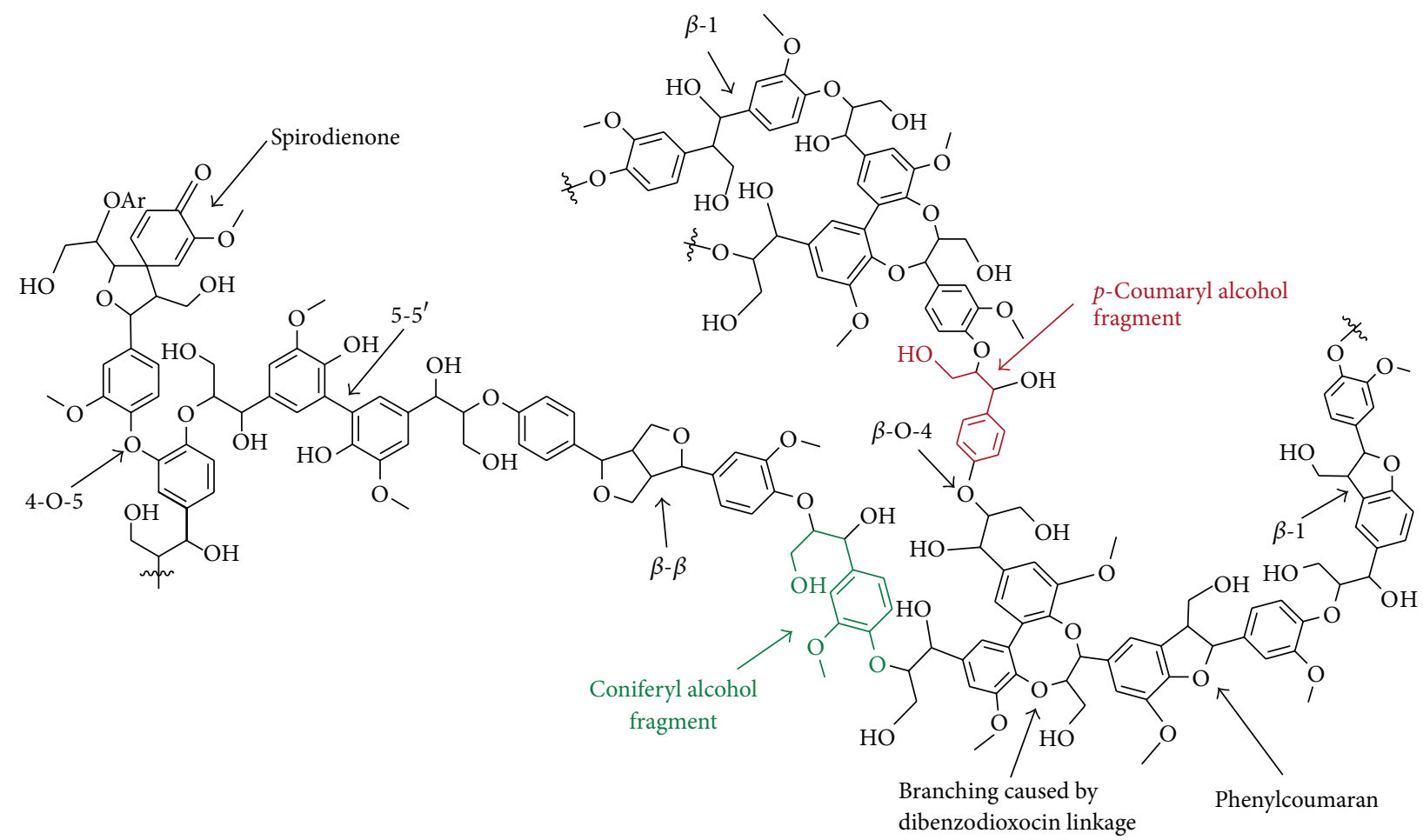

FIGURE 1: Structure of a softwood lignin molecule showing the prominent linkage types. With permission from Zakzeski et al. [40].

along additional process steps and higher cost. Besides photocatalysis, lignin can be degraded by other ways such as biochemical degradation through microbial/enzymatic attack [7-9], thermal degradation [10, 11], and electrochemical oxidation [12].

For a good catalytic efficiency in an immobilized catalytic system, a good hydrodynamic design of the system and modifications involving the utilization of the visible light spectrum by catalyst doping can be of great importance. The selection and design of the supporting material influence both the fluidic design and the available catalyst surface. The photocatalytic efficiency increases with an increase in active surface. This means the carrier material has to provide a high surface to volume ratio. Also, the materials used as supports for photocatalytic purposes must also fulfill stringent optical properties such as transparency to UV-A light, in order to achieve high photonic efficiencies and to minimize the energy consumption required for the illumination.

The goal of this work is to describe stable catalytic coatings produced on porous glass material and report their photocatalytic activity which was studied by degradation experiments of lignin under UV light illumination. Sintered glass particles were coated to exploit the advantages of a heterogeneous system and a good fluidic design was attained by the porosity of the glass particles. Moreover, parameters such as flow characterization and irradiance which are required for the rigorous design and the scaling up of a photocatalytic reactor in order to accomplish a commercial application are treated in this paper. Additionally a simultaneous reactionextraction pathway, applying dialysis filtration and highly porous polystyrene divinylbenzene adsorbent resin (HR-P), was applied. In this work, a relatively high concentration of lignin sulfonate $(0.5 \mathrm{~g} / \mathrm{L})$ obtained from a local paper company is used.

Furthermore, this paper presents a reaction design which can remediate the pollution problem in waste water discharged from pulp and paper mills on the one hand and, on the other hand, gives room to further exploit the degradation of lignin as an alternative chemical source. Results obtained from the time dependent degradation gives an opportunity to achieve defined chemical structures when isolated. Peaks observed by both high performance liquid (HPLC) and fluorescence chromatograms suggest the production of new substances and lignin sulfonate.

1.1. Degradation and Mineralization of Lignin. Lignin degradation is generally in the range of lower energy (between 300 and $400 \mathrm{~nm}$ ) because of its multifunctional character [13-15]. For a better illustration, Figure 1 shows the structure of a softwood lignin fragment containing all prominent linkage types. During the photodegradation process of lignin, radical sites and excited $\alpha$-carbonyl are involved. Excited $\alpha$ carbonyl groups are able to abstract hydrogen from some lignin units, preferably phenolic hydrogen, initiating an oxidative chain reaction with the participation of groundstate oxygen, leading to the fragmentation and the formation of new chromophores, dimers, and sometimes oligomers as major products [16]. The action of hydroxyl radicals can induce the formation of radical sites on a substrate, thus inducing further oxidation or disproportionation reactions. 
The process can be accelerated by oxygen [17]. Machado et al. [18] report a rapid initial decrease of phenolic hydroxyl groups followed by a clear tendency to increase explained as an effect of incorporation of hydroxyl groups on aromatic rings, occurring by hydroxylation and/or demethoxylation [17]. The below equation summarizes the formation of singlet oxygen, hydroxyl, and superoxide radicals as principal reactive species in a photocatalytic process $[19,20]$. $S$ stands for the lignin substrate while $\mathrm{TiO}_{2}\left(\mathrm{~h}^{+}\right)$and $\mathrm{TiO}_{2}\left(\mathrm{e}^{-}\right)$represent the electron-deficient and electron-rich parts in the structure of $\mathrm{TiO}_{2}$, respectively. Consider

$$
\begin{gathered}
\mathrm{TiO}_{2} \stackrel{h v}{\longrightarrow} \mathrm{TiO}_{2}\left(\mathrm{e}^{-} / \mathrm{h}^{+}\right) \\
\mathrm{TiO}_{2}\left(\mathrm{~h}^{+}\right)+\mathrm{H}_{2} \mathrm{O} \longrightarrow \mathrm{TiO}_{2}+\mathrm{HO}^{\bullet}+\mathrm{H}^{+} \\
\mathrm{TiO}_{2}\left(\mathrm{~h}^{+}\right)+\mathrm{S} \longrightarrow \mathrm{TiO}_{2}+\mathrm{S}^{+\cdot} \\
\mathrm{TiO}_{2}\left(\mathrm{~h}^{+}\right)+\mathrm{HO}^{-} \longrightarrow \mathrm{TiO}_{2}+\mathrm{HO} \\
\mathrm{TiO}_{2}\left(\mathrm{e}^{-}\right)+\mathrm{O}_{2} \longrightarrow \mathrm{TiO}_{2}+{ }^{\cdot} \mathrm{O}_{2}^{-} \\
\mathrm{HO}^{-}+\mathrm{O}_{2} \longrightarrow \mathrm{HO}^{\cdot}+{ }^{\cdot} \mathrm{O}_{2}^{-} \\
\mathrm{HO}^{-}+{ }^{-} \mathrm{O}_{2}{ }^{-} \longrightarrow \mathrm{HO}^{-}+{ }^{1} \mathrm{O}_{2}
\end{gathered}
$$

\section{Experimental}

2.1. Flow Measurements. The reaction design consisted of $\mathrm{TiO}_{2}$ coatings on sintered glass $(150-250 \mu \mathrm{m}$ nominal pore size), packed in a borosilicate tube $26 \mathrm{~cm}$ long, $1 \mathrm{~cm}$ outer diameter, and $6 \mathrm{~mm}$ internal diameter. Glass particle grain size was between 200 and $400 \mu \mathrm{m}$. The packed bed reactor design had advantages such as a constant plug flow and therefore a narrow residence time distribution and good mixing condition with the sintered glass acting as static mixer.

For fluid flow through a bed of approximately spherical particles, the Reynold number (Re) used to characterize laminar or turbulent flow regimes is defined as follow [21]:

$$
\operatorname{Re}=\frac{\rho V D}{\mu(1-\varepsilon)},
$$

where $\rho$ is the density of lignin sulfonate solution $\left(\mathrm{kg} / \mathrm{m}^{3}\right)$, $\mu$ is the dynamic viscosity of $0.5 \mathrm{~g} / \mathrm{L}$ lignin sulfonate solution $(\mathrm{Pa} \cdot \mathrm{S}), \varepsilon$ is the voidage and $V$ is the superficial velocity $(\mathrm{m} / \mathrm{s})$. The voidage was calculated from the correlation equation of packed beds [22].

The voidage was calculated from the correlation equation of packed beds [22]:

$$
\varepsilon=0.293+(0.684) \mathrm{dr}^{-0.85} \cdot \frac{1}{(1.837 \mathrm{dr}-1)^{0.5}},
$$

where $\mathrm{dr}=\mathrm{dt} / \mathrm{dp}$, $\mathrm{dt}$ is diameter of tube and $\mathrm{dp}$ is diameter of particle.

The particle must be spherical and $\mathrm{dr}>1.86$ [22].

The superficial velocity $V$ was calculated from

$$
V=\frac{\text { volume flow rate }}{\text { cross sectional area of tube }} .
$$

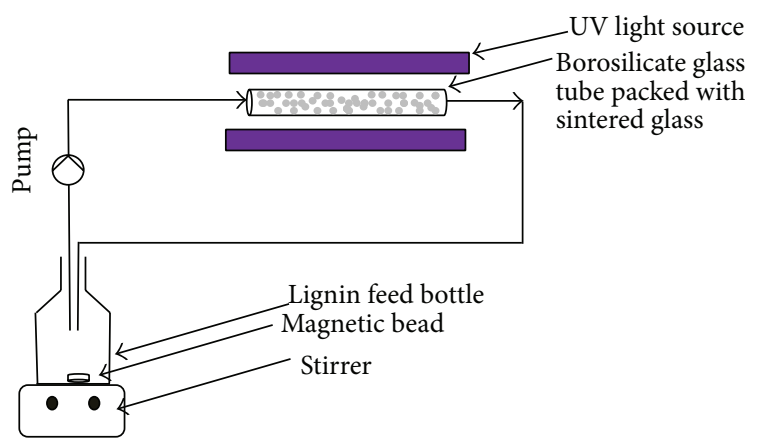

FIGURE 2: Experimental setup for the photocatalytic degradation of lignin.

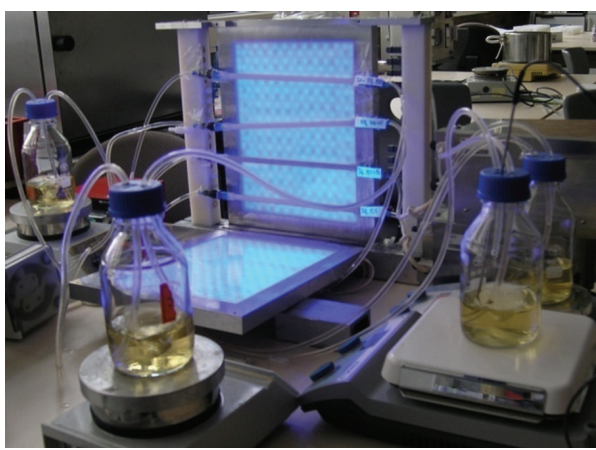

FIgURE 3: Photocatalytic reactor.

2.2. Photocatalytic Experiments. The degradation experiments of lignin sulfonate were carried out with a starting concentration of $0.5 \mathrm{~g} / \mathrm{L}$ in $200 \mathrm{~mL}$ deionized water. The tube was placed between two planar dielectric barrier discharge lamps. The broad surface of the light source insured incident light is well distributed all over the surface of the glass tubes. Figure 2 depicts the reaction setup while Figure 3 illustrates the reactor used for the experiments.

The reaction procedure involved 3 pathways. In the first one, lignin sulfonate solution was pumped through the reactor using roller pumps in a continuous manner with a flow rate of $22.5 \mathrm{~mL} / \mathrm{min}$. Samples were collected at intervals up to a period of $20 \mathrm{~h}$ reaction time. Reactions were carried out at room temperature. Blank experiments were performed in the absence of UV light illumination as well as with uncoated sintered glass tubes. For all experiments, lignin was recirculated through the reactor for $60 \mathrm{~min}$ before UVlight was put on. This was to ensure uniform wettability within the packed bed and same starting reaction conditions for all experiments. The second procedure involved a reaction-extraction pathway in which extraction followed after reaction with the use of highly porous polystyrene divinylbenzene adsorbent resin (HR-P). In the third procedure, the reactor was connected to a dialysis filter fitted with a HRP extraction column operating in a cycle process. This is depicted in Figure 4. Its aim was to directly extract smaller molecules produced and preferably aromatic and phenol-like compounds from the aqueous medium. 


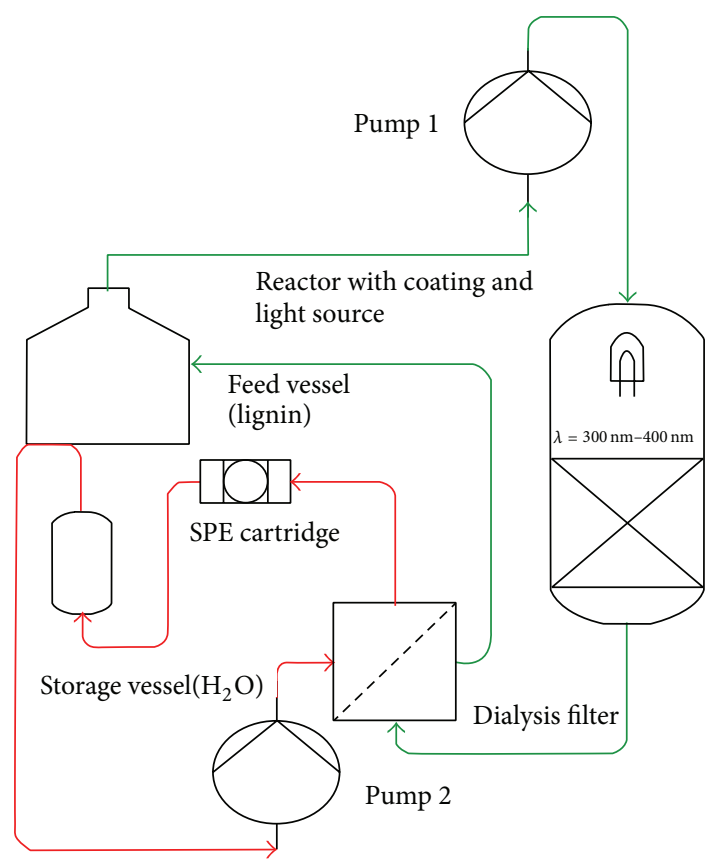

Figure 4: Photocatalytic cycle process with integrated solid phase extraction and dialysis membrane.

2.3. Analytical Method. The concentration of lignin in the reaction mixture was determined by correlating absorbance of an aliquot solution to the calibration curve of lignin at different concentrations. This was done using a UVvisible (Thermo-Scientific Genesys 10S) spectrophotometer (at $203 \mathrm{~nm}$ and $280 \mathrm{~nm}$ ) with deionized water as reference. The percentage degradation was calculated as follows:

$$
\text { Degradation }(\%)=\left(\frac{C-C_{0}}{C_{0}}\right) \times 100 \text {. }
$$

$C_{0}$ is the initial concentration of lignin and $C$ is the concentration of lignin after photo-irradiation. The photocatalytic decomposition of the organic molecules follows the Langmuir-Hinshelwood kinetics, which may be represented as $[23,24]$

$$
\frac{-\mathrm{d} C}{\mathrm{dt}}=-k C C_{\mathrm{HO}}
$$

where $C$ is the concentration of lignin and $C_{\mathrm{HO}}$. the hydroxyl radical concentration. By the pseudostationary hypothesis (i.e., the $C_{\mathrm{HO}}$ - can be considered to be constant because of the continuous hydroxyl ion generation by photocatalysis) the rate depends only on the lignin concentration [25]. The rate expression can be written as follows:

$$
-\ln \left(\frac{C}{C_{0}}\right)=k t
$$

where the linear plot of $\ln \left(C / C_{0}\right)$ versus $t$ gives the rate constant, $k$ (slope).

Dissolved carbon (DC) content of lignin sulfonate over time was done using a TOC analyser (Shimadzu TOC5000A). High performance liquid chromatography (HPLC) and fluorescence measurements were done on an HP1090 liquid chromatograph and HP1040A programmable fluorescence detector, respectively.

2.4. Material. Lignin sulfonate waste water was obtained from a local producing paper company (Sappi-Ehingen AG). Cross flow filtration was applied using ceramic membranes of $0.2 \mu \mathrm{m}$ and $20 \mathrm{kD}$ membrane to isolate lignin. The concentrated lignin sulfonate solution was then dried in a laboratory drying chamber at $40^{\circ} \mathrm{C}$ for several days in order to avoid mold and to ensure constant concentration during dissolution. $\mathrm{ZnO}\left(5 \mathrm{~m}^{2} / \mathrm{g}\right)$ and chloroplatinic acid hydrate (99.999\%) were purchased from Sigma-Aldrich, Germany, and titanium (IV) oxide sulfate dihydrate (titanyloxyssulfate) was purchased from Alfa Aesar. Aeroxide $\mathrm{TiO}_{2}-\mathrm{P} 25$ (surface area $50 \mathrm{~m}^{2} / \mathrm{g}$ and average particle size $30 \mathrm{~nm}$ ) was obtained from Evonik and consisted of $70 \%$ anatase and $30 \%$ rutile. tetraethyl orthosilicate (TEOS) was purchased from Merck. Borosilicate glass tubes containing sintered glass particles were purchased from ROBU, Germany. Polystyrene divinylbenzene adsorbent resin, Chromabond (HR-P) was purchased from Macherey Nagel. The dialysis filter was an ultraflux AV Paed (surface area $0.2 \mathrm{~m}^{2} / \mathrm{g}$ and with high cut off, average pore size $<0.02 \mu \mathrm{m}$ ). UV-A meter was purchased from Dr. Honle UV Technology. All chemicals were used as received.

2.5. Preparation of Catalyst and Coating Procedure. The following catalysts were synthesized: $\mathrm{TiO}_{2}-\mathrm{P} 25-\mathrm{SiO}_{2}+\mathrm{Pt}, \mathrm{TiO}_{2}-$ $\mathrm{P} 25-\mathrm{SiO}_{2}, \mathrm{ZnO}+\mathrm{TiO}_{2}-\mathrm{P} 25-\mathrm{SiO}_{2}$, and $\mathrm{TiOSO}_{4}-30.6$ wt $\%$. A detailed description of the catalysts synthesis and coating has been described elsewhere [26].

\section{Results and Discussion}

3.1. Morphology of Coating and Surface Area. Scanning electron microscopy (SEM) was the primary tool for characterizing the surface morphology and fundamental physical properties of the material surface such as porosity and distribution of the coating. In Figure 5, SEM images are shown for uncoated and coated glass with different catalysts. Samples consisted of sintered glass plates cut to a size of $1 \mathrm{~cm}^{2}$ dipped into the gel or suspension. Drying and calcination were done same as was the case with borosilicate glass tubes [26]. The micrographs for the uncoated sintered glass in Figures 5(a) and 5(b) show structures formed by glass particles of approximately $200-400 \mu \mathrm{m}$ in size sintered together. Figures 5(c) $-5(\mathrm{~h})$ shows micrographs of the coated glass material. Figures 5(e) and 5(h) consist of a double coating whereby TEOS was first coated and $\mathrm{TiO}_{2}-\mathrm{P} 25$ follows. Significant agglomeration of the particles is also observed. Some fissures are also seen at joints between sintered particles and on the glass particles as a result of drying. It is worthwhile noting that these micrographs originate from sintered glass plates whereby the drying mechanism could be harsher as heat radiations directly strike on them as compared to a borosilicate glass tube encaging sintered glass particles. 


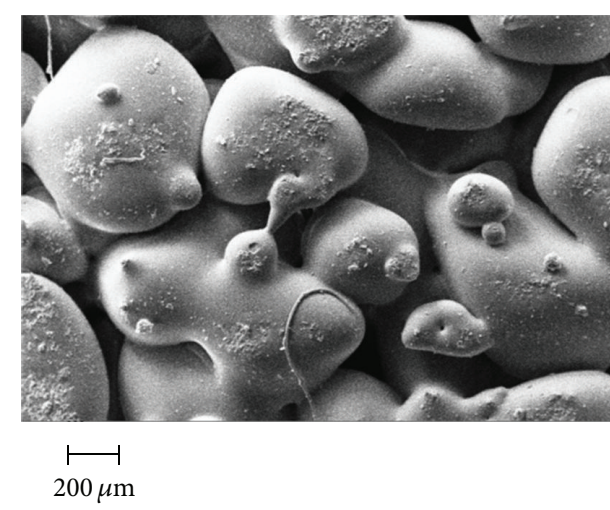

(a)

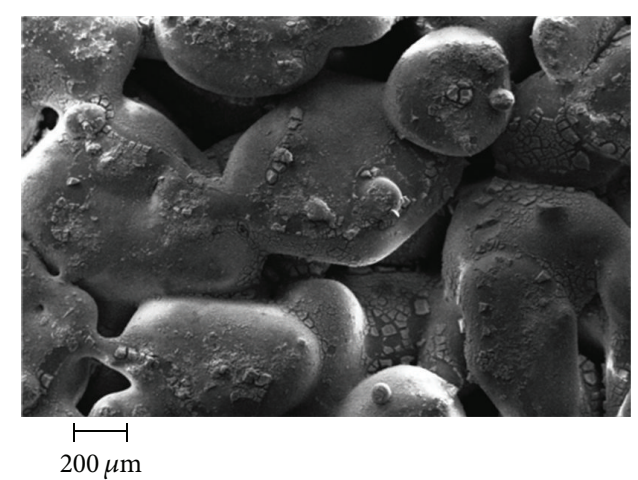

(c)

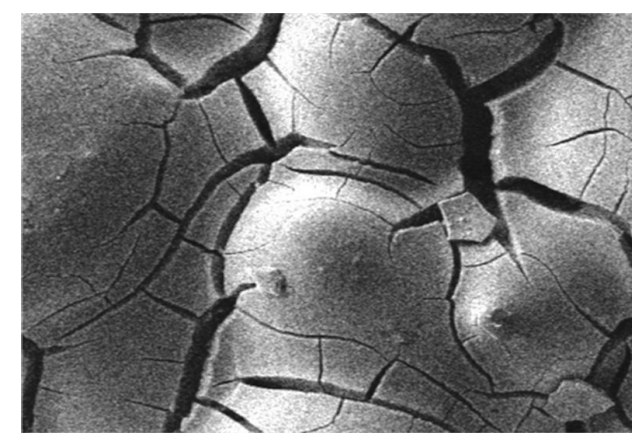

$100 \mu \mathrm{m}$

(e)

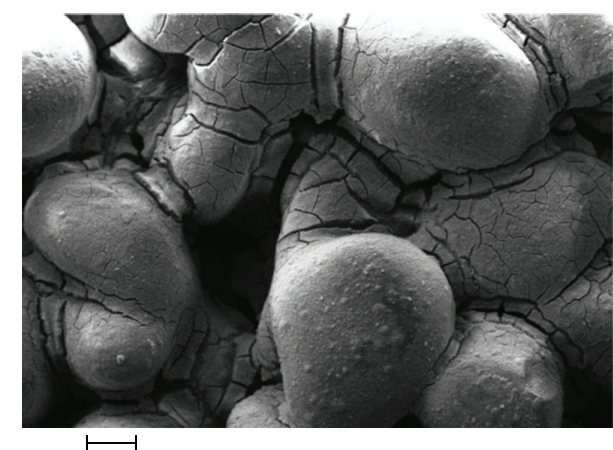

$200 \mu \mathrm{m}$

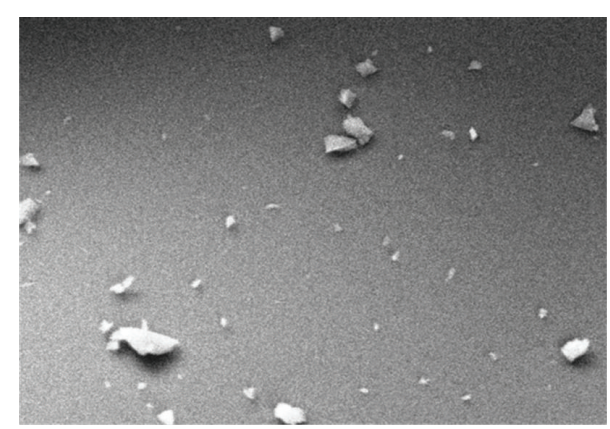

$\stackrel{\longmapsto}{10 \mu \mathrm{m}}$

(b)

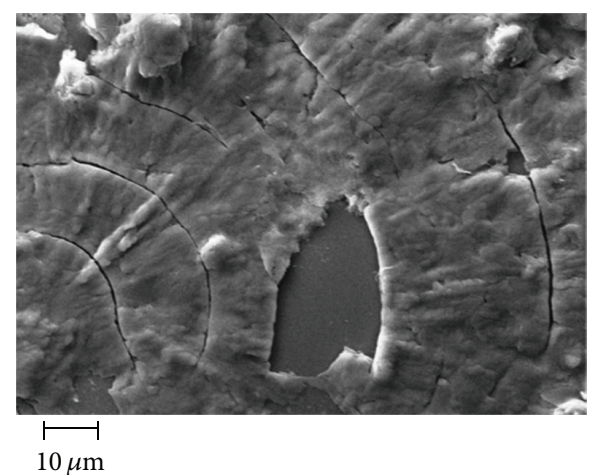

(d)

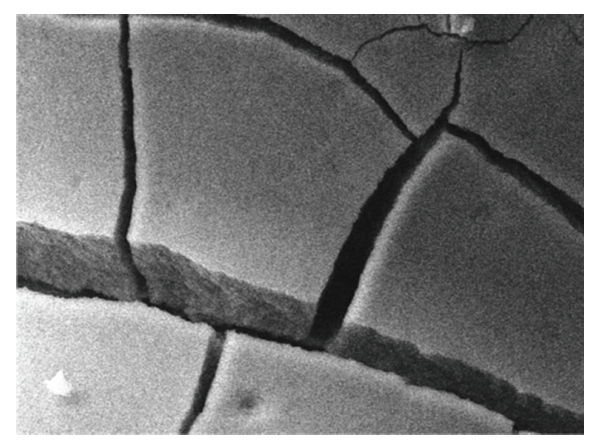

$$
\stackrel{\longmapsto}{\longmapsto} 10 \mathrm{~m}
$$

(f)

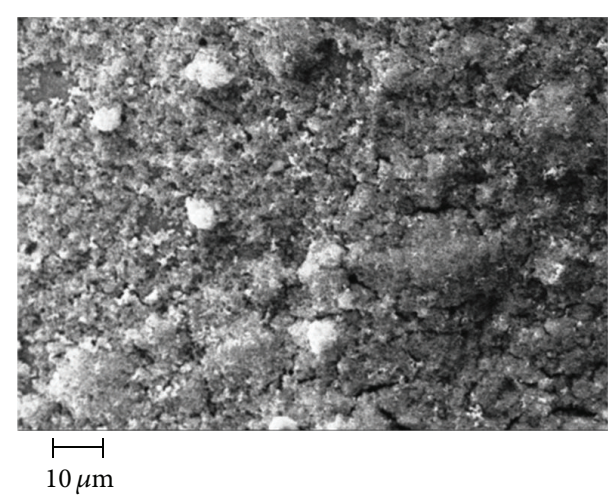

(h)

Figure 5: SEM images for uncoated borosilicate sintered glass ((a) and (b)), $\mathrm{TiO}_{2}\left(\mathrm{TiOSO}_{4} 30.6 \mathrm{wt} \%\right)$ coating on borosilicate glass ((c) and (d)), $\mathrm{TiO}_{2}-\mathrm{P} 25-\mathrm{SiO}_{2}\left((\mathrm{e})\right.$ and (f)), and $\mathrm{ZnO}+\mathrm{TiO}_{2}-\mathrm{P} 25-\mathrm{SiO}_{2}((\mathrm{~g})$ and $(\mathrm{h}))$. 
TABLE 1: Parameters used to calculate the flow characteristic of photocatalytic reactor.

\begin{tabular}{lccccccc}
\hline$R_{i, \text { tube }}$ & $A_{\text {tube }}\left(\mathrm{m}^{2}\right)$ & $\rho_{\text {lignin }}\left(\mathrm{kg} / \mathrm{m}^{3}\right)$ & $V_{\text {lignin }}(\mathrm{m} / \mathrm{s})$ & $D_{\text {particles }}(\mu \mathrm{m})$ & $\mu_{\text {lignin }}(\mathrm{kg} / \mathrm{ms})$ & $\varepsilon($ voidage $)$ & Re \\
\hline $0.30 \mathrm{~cm}$ & $2.83 \times 10^{-5}$ & 1000 & 0.013 & 300 & $1 \times 10^{-4}$ & 0.30 & 56 \\
\hline
\end{tabular}

It can be observed that the coatings have a crystalline structure and are considerably well distributed all over the surface of the sintered glass. Rutile is known to be the stable phase of $\mathrm{TiO}_{2}$ whereas anatase and brookite are metastable at all temperatures and transform to rutile when they are heated. From the calcination temperature of $500^{\circ} \mathrm{C}$, the crystal phases involved both rutile and anatase since the transformation of anatase to rutile is in the temperature range between 600 and $700^{\circ} \mathrm{C}$ [27]. Moreover anatase is typically the majority product of inorganic syntheses and is the main constituent of nanocrystalline materials [28]. Aeroxide $\mathrm{TiO}_{2}-\mathrm{P} 25$ obtained from Evonik consisted of $70 \%$ anatase and $30 \%$ rutile.

3.2. Reactor Characterization. For packed bed reactors, laminar conditions apply when $\mathrm{Re}<2000$ and fully turbulent from 2000 [21]. Using (2), a value of 56 was obtained which characterizes a laminar flow. Table 1 outlines the flow characterization values.

The weight of coating on the glass tubes was in the range of $0.12 \mathrm{~g}-0.19 \mathrm{~g}$. The BET specific surface area of a borosilicate tube containing the sintered glass particle was $0.015 \mathrm{~m}^{2} / \mathrm{g}$ making a total of $0.17 \mathrm{~m}^{2}$ for $11.5 \mathrm{~g}$ glass particles in the borosilicate glass tube.

UV-light was from two planar dielectric barrier discharge lamps (Osram Planon) emitting UV-light in the range of 280$420 \mathrm{~nm}$. The irradiance determined by UV-A radiometric measurements was between 30 and $40 \mathrm{~W} / \mathrm{m}^{2}$.

\section{Results and Discussion}

4.1. Degradation Experiments. Figure 6 shows a time dependent UV-Vis spectra of lignin sulfonate. Absorption peaks were observed at $203 \mathrm{~nm}$ and $280 \mathrm{~nm}$ while a shoulder at around $230 \mathrm{~nm}$ was observed. Lignin absorbs UV light with high molar extinction coefficients because of the several methoxylated phenylpropane units of which they are composed [29]. The absorption peaks decrease gradually indicating the decomposition of lignin sulfonate and hence deterioration of the present chromophore groups. Peaks around $203 \mathrm{~nm}$ correspond to portions of unsaturated chains $[29,30]$ while those around $280 \mathrm{~nm}$ correspond to unconjugated phenolic hydroxyl groups [31] and aromatic rings [30] of lignin sulfonate. Ohnishi et al. [30] report the absorption tailing arising from the color of lignin.

Preliminary reactions carried out involved lignin sulfonate degradation experiments performed on uncoated glass in the presence of UV-light as well as on coated glass particles in the absence of UV-light. Results obtained revealed no significant change in absorbance over a $20 \mathrm{~h}$ period indicating no major degradation and adsorption. Houas et al. [24] note that, at catalytic surfaces experiencing unfavourable conditions such as repellent interactions, there may be no

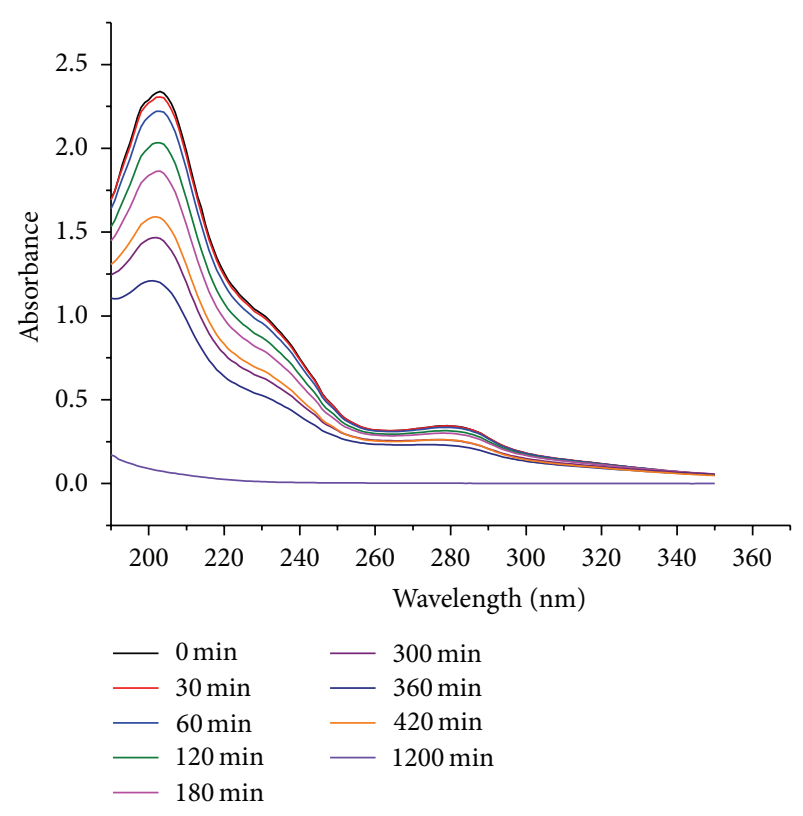

FIgURE 6: Time dependent UV-Vis absorption spectra of aqueous lignin sulfonate solution. Concentration: $0.5 \mathrm{~g} / \mathrm{L}$ in $200 \mathrm{~mL}$, reaction time: 20 h, catalyst: sol-gel derived $\mathrm{TiO}_{2}-\mathrm{P} 25-\mathrm{SiO}_{2}$, reaction at room temperature, and UV radiation $(280-420 \mathrm{~nm})$.

adsorption. It can further be argued that because of the nature of lignin used in this work (lignin sulfonate) the sulfonate groups attached to lignin render it anionic. Likewise because of the basic nature of the reaction medium $(\mathrm{pH} 9)$ and the negatively charged hydroxyl $\left(\mathrm{OH}^{-}\right)$ions generated from photochemical reactions, adsorption conditions do not prevail.

Figures 7 and 8 depict the degradation of lignin sulfonate by different catalysts at wavelengths $203 \mathrm{~nm}$ and $280 \mathrm{~nm}$, respectively. Degradation of lignin sulfonate prevailed in the presence of a catalyst. An abrupt degradation increase was observed for $\mathrm{TiOSO}_{4} 30.6 \mathrm{wt} \%$ and $\mathrm{ZnO}+\mathrm{TiO}_{2}-\mathrm{P} 25-$ $\mathrm{SiO}_{2}$ catalysts between $240 \mathrm{~min}$ and $300 \mathrm{~min}$. Here, the slow reaction at the beginning is the rate determining step [32]. In this step, processes such as absorption of photons of light by catalyst and production of electrons and other oxidizing species take place before a faster reaction takes place [33]. An almost linear degradation pattern was noted for $\mathrm{TiO}_{2}$ $\mathrm{P} 25-\mathrm{SiO}_{2}+\mathrm{Pt}$ and $\mathrm{TiO}_{2}-\mathrm{P} 25-\mathrm{SiO}_{2}$ throughout the complete reaction time. Degradation rates of $97 \%, 95 \%, 87 \%$, and $51 \%$ were attained by coatings $\mathrm{TiO}_{2}-\mathrm{P} 25-\mathrm{SiO}_{2}+\mathrm{Pt}, \mathrm{TiO}_{2}-\mathrm{P} 25-$ $\mathrm{SiO}_{2}, \mathrm{ZnO}+\mathrm{TiO}_{2}-\mathrm{P} 25-\mathrm{SiO}_{2}$, and $\mathrm{TiOSO}_{4} 30.6 \mathrm{wt} \%$, respectively, after $20 \mathrm{~h}$ reaction time for the straight chain lignin sulfonate moiety (Figure 7). Similar degradation values are 


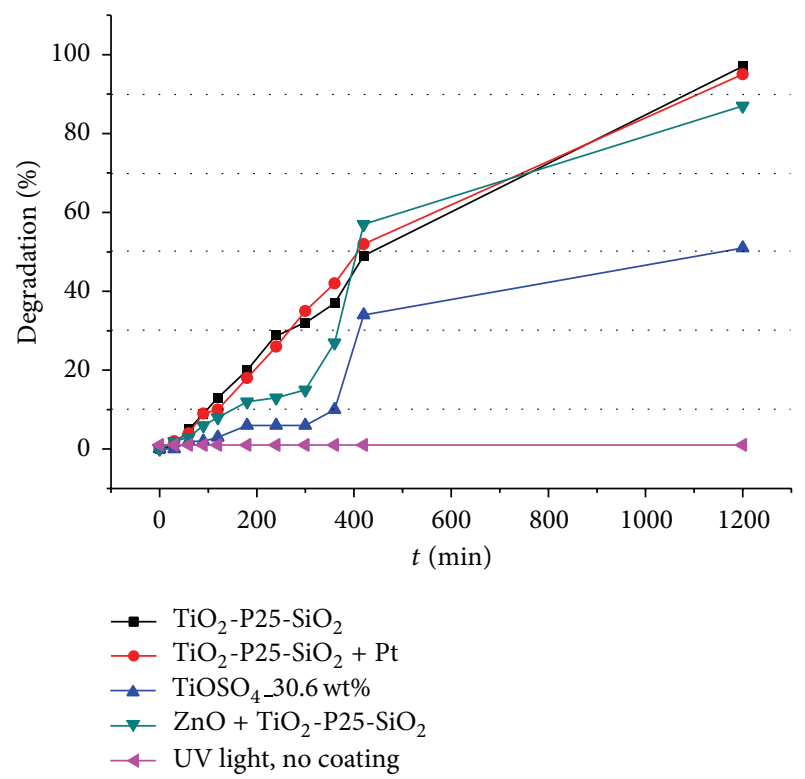

FIGURE 7: Effect of different catalyst on percentage degradation of lignin sulfonate under UV light at wavelength $203 \mathrm{~nm}$ (lignin sulfonate concentration: $0.5 \mathrm{~g} / \mathrm{L}$ in $200 \mathrm{~mL}$, reaction time: $20 \mathrm{~h}$, reaction at room temperature, and UV radiation $(280-420 \mathrm{~nm})$ ).

also observed for the aromatic moiety after $20 \mathrm{~h}$ (Figure 8). $\mathrm{TiOSO}_{4}-30.6 \mathrm{wt} \%$ catalyst was less reactive compared to the others because of the relatively low degradation values it produced. Less than $40 \%$ degradation was achieved after $420 \mathrm{~min}$ for both the aromatic and aliphatic moiety. Comparing the degradation rates of the aromatic moiety against that of the straight chain moiety after 420 mins, it was observed that higher degradation values were attained by the aliphatic moiety. In detail, for the aliphatic moiety degradation rates of $49 \%, 52 \%, 57 \%$, and $34 \%$ were noted while for the aromatic moiety degradation rates of $34 \%, 32 \%, 41 \%$, and $36 \%$ were observed for $\mathrm{TiO}_{2}-\mathrm{P} 25-\mathrm{SiO}_{2}+\mathrm{Pt}, \mathrm{TiO}_{2}-\mathrm{P} 25-\mathrm{SiO}_{2}, \mathrm{ZnO}$ $+\mathrm{TiO}_{2}-\mathrm{P} 25-\mathrm{SiO}_{2}$, and $\mathrm{TiOSO}_{4}-30.6 \mathrm{wt} \%$, respectively. This suggests a faster transformation of the aliphatic side chains as compared to the aromatic species. A similar conclusion was arrived at by Tanaka et al. [34] whereby FTIR measurements were applied.

Comparing the degradation values of lignin sulfonate by using plain $\mathrm{TiO}_{2}-\mathrm{P} 25-\mathrm{SiO}_{2}$ and that of the combination between $\mathrm{ZnO}$ and $\mathrm{TiO}_{2}-\mathrm{P} 25-\mathrm{SiO}_{2}$, a higher degradation rate was observed for $\mathrm{ZnO}$ and $\mathrm{TiO}_{2}-\mathrm{P} 25-\mathrm{SiO}_{2}$ after 420 mins, both for the straight chain moiety and aromatic moiety. However after $20 \mathrm{~h}$ reaction time, $\mathrm{TiO}_{2}-\mathrm{P} 25-\mathrm{SiO}_{2}$ had a higher degradation value, both for the straight chain moiety and aromatic moiety. Degradation rates of $49 \%$ and $57 \%$ were observed after 420 minutes for $\mathrm{TiO}_{2}-\mathrm{P} 25-\mathrm{SiO}_{2}$ and $\mathrm{ZnO}+$ $\mathrm{TiO}_{2}-\mathrm{P} 25-\mathrm{SiO}_{2}$ catalysts, respectively. Meanwhile after $20 \mathrm{~h}$ reaction time, values of $97 \%$ and $87 \%$ are attained by $\mathrm{TiO}_{2}$ $\mathrm{P} 25-\mathrm{SiO}_{2}$ and $\mathrm{ZnO}+\mathrm{TiO}_{2}-\mathrm{P} 25-\mathrm{SiO}_{2}$ catalysts, respectively. This means $\mathrm{ZnO}+\mathrm{TiO}_{2}-\mathrm{P} 25-\mathrm{SiO}_{2}$ catalyst was more active during the first 420 mins and its activity decreased in the proceeding time.

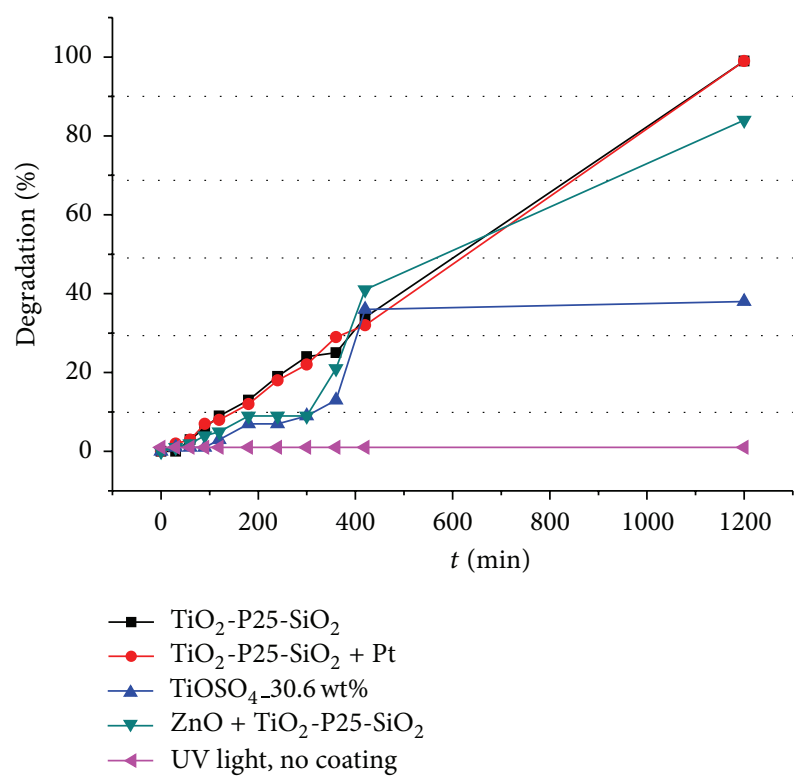

FIGURE 8: Effect of different catalyst on percentage degradation of lignin sulfonate under UV light at wavelength $280 \mathrm{~nm}$ (lignin sulfonate concentration: $0.5 \mathrm{~g} / \mathrm{L}$ in $200 \mathrm{~mL}$, reaction time: $20 \mathrm{~h}$, reaction at room temperature, and UV radiation $(280-420 \mathrm{~nm})$ ).

Adding (doping) $\mathrm{Pt}$ as metal ion to $\mathrm{TiO}_{2}-\mathrm{P} 25-\mathrm{SiO}_{2}$ slightly improved the degradation values compared to that of plain $\mathrm{TiO}_{2}-\mathrm{P} 25-\mathrm{SiO}_{2}$ catalyst. Values of $49 \%$ and $52 \%$ are attained after 420 minutes reaction time for $\mathrm{TiO}_{2}-\mathrm{P} 25-\mathrm{SiO}_{2}$ and $\mathrm{TiO}_{2}-\mathrm{P} 25-\mathrm{SiO}_{2}+\mathrm{Pt}$ catalysts, respectively, whereas, after $20 \mathrm{~h}$ reaction time, values of $97 \%$ and $95 \%$ are attained by $\mathrm{TiO}_{2}-\mathrm{P} 25-\mathrm{SiO}_{2}$ and $\mathrm{TiO}_{2}-\mathrm{P} 25-\mathrm{SiO}_{2}+\mathrm{Pt}$ catalysts, respectively. These results indicate Pt contributed little or no change in degradation rate which is contradictory to some published results on the effect of doping $[35,36]$. However, for reactions in which doping enhances degradation, a threshold dosage has to be considered [36].

In order to effectively quantify lignin degradation, dissolved carbon (DC) measurements were done (Figure 9). DC describes the amount of carbon bound in a compound. DC in lignin sulfonate of initial concentration $500 \mathrm{mg} / \mathrm{L}$ decreased from $185 \mathrm{ppm}$ to $144 \mathrm{ppm}, 121 \mathrm{ppm}, 159 \mathrm{ppm}$, and $143 \mathrm{ppm}$ after 420 mins for the catalysts $\mathrm{TiO}_{2}-\mathrm{P} 25-\mathrm{SiO}_{2}, \mathrm{TiO}_{2}-\mathrm{P} 25$ $\mathrm{SiO}_{2}+\mathrm{Pt}, \mathrm{ZnO}+\mathrm{TiO}_{2}-\mathrm{P} 25-\mathrm{SiO}_{2}$, and $\mathrm{TiOSO}_{4}-30.6 \mathrm{wt} \%$, respectively. This value further decreased to $31 \mathrm{ppm}, 33 \mathrm{ppm}$, $122 \mathrm{ppm}$, and $71 \mathrm{ppm}$ making a DC removal of $84 \%, 82 \%, 61 \%$, and $34 \%$ for $\mathrm{TiO}_{2}-\mathrm{P} 25-\mathrm{SiO}_{2}, \mathrm{TiO}_{2}-\mathrm{P} 25-\mathrm{SiO}_{2}+\mathrm{Pt}, \mathrm{ZnO}+$ $\mathrm{TiO}_{2}-\mathrm{P} 25-\mathrm{SiO}_{2}$, and $\mathrm{TiOSO}_{4}-30.6 \mathrm{wt} \%$, respectively. Hence, $\mathrm{TC}$ removal was in the order of $\mathrm{TiO}_{2}-\mathrm{P} 25-\mathrm{SiO}_{2}+\mathrm{Pt} \sim \mathrm{TiO}_{2}$ $\mathrm{P} 25-\mathrm{SiO}_{2}>\mathrm{ZnO}+\mathrm{TiO}_{2}-\mathrm{P} 25-\mathrm{SiO}_{2}>\mathrm{TiOSO}_{4} 30.6 \mathrm{wt} \%$. Decrease in $\mathrm{DC}$ has been reported to generate carbon dioxide and a small amount of carbon monoxide as the main gaseous products [35].

The rate constant values for the different catalysts are shown in Figure 10. Reaction rate was in the order of $\mathrm{TiO}_{2}$ $\mathrm{P} 25-\mathrm{SiO}_{2}+\mathrm{Pt} \sim \mathrm{TiO}_{2}-\mathrm{P} 25-\mathrm{SiO}_{2}>\mathrm{ZnO}+\mathrm{TiO}_{2}-\mathrm{P} 25-\mathrm{SiO}_{2}>$ 


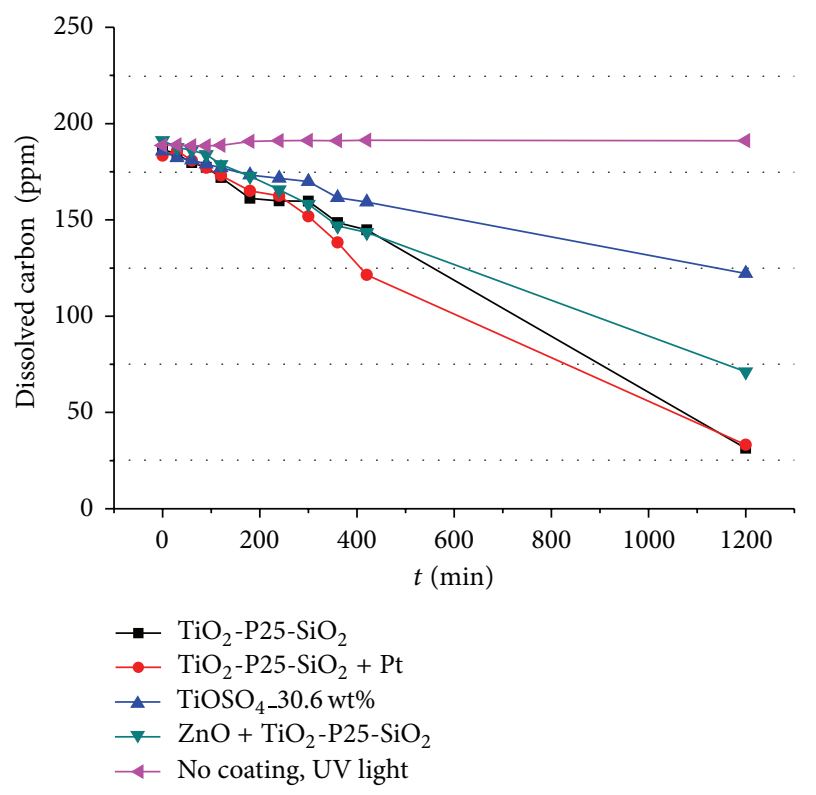

FIGURE 9: Removal of dissolved carbon in lignin sulfonate. Concentration: $0.5 \mathrm{~g} / \mathrm{L}$ in $200 \mathrm{~mL}$, reaction time: $20 \mathrm{~h}$, reaction at room temperature, and UV radiation $(280-420 \mathrm{~nm})$.

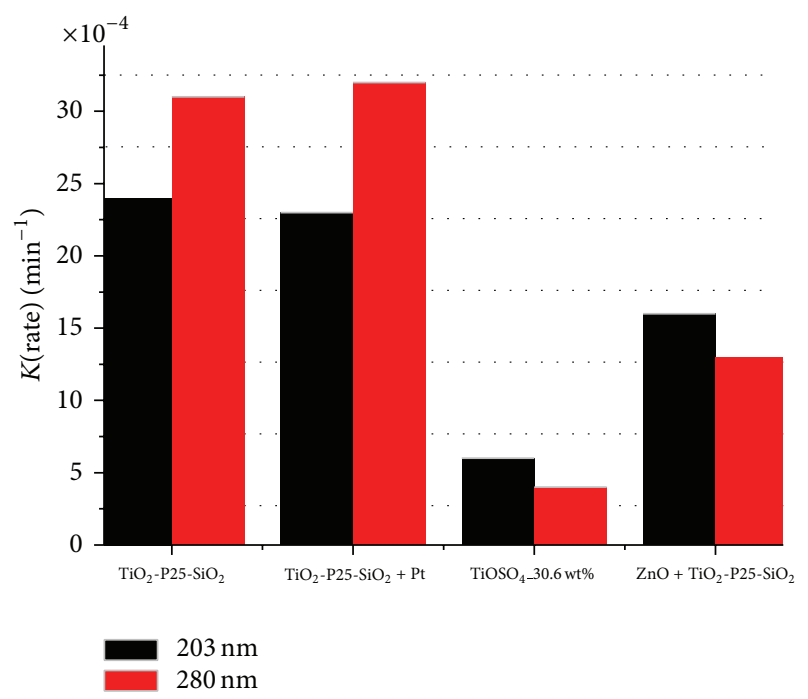

FIGURE 10: Reaction rates of the photocatalytic degradation of lignin sulfonate $(500 \mathrm{mg} / \mathrm{L})$ under UV light on immobilized catalysts. Concentration: $0.5 \mathrm{~g} / \mathrm{L}$ in $200 \mathrm{~mL}$, reaction time: $20 \mathrm{~h}$, reaction at room temperature, and UV radiation (280-420 $\mathrm{nm}$ ).

$\mathrm{TiOSO}_{4} 30.6 \mathrm{wt} \%$ for both the aromatic and aliphatic side chain wavelength regions.

Comparing $\mathrm{ZnO}+\mathrm{TiO}_{2}-\mathrm{P} 25-\mathrm{SiO}_{2}$ and $\mathrm{TiO}_{2}-\mathrm{P} 25-\mathrm{SiO}_{2}$ and adding $\mathrm{ZnO}$ to $\mathrm{TiO}_{2}-\mathrm{P} 25-\mathrm{SiO}_{2}$ had an adverse effect on reaction rate probably because $\mathrm{ZnO}$ occupies some of the active sites on the catalyst support and it does not optimally absorb UV light in the domain of the wave lengths transmitted by the photo reactor $(280<\lambda<420 \mathrm{~nm})$ and, as a consequence, limitations in electron transfer between the band gaps [37].

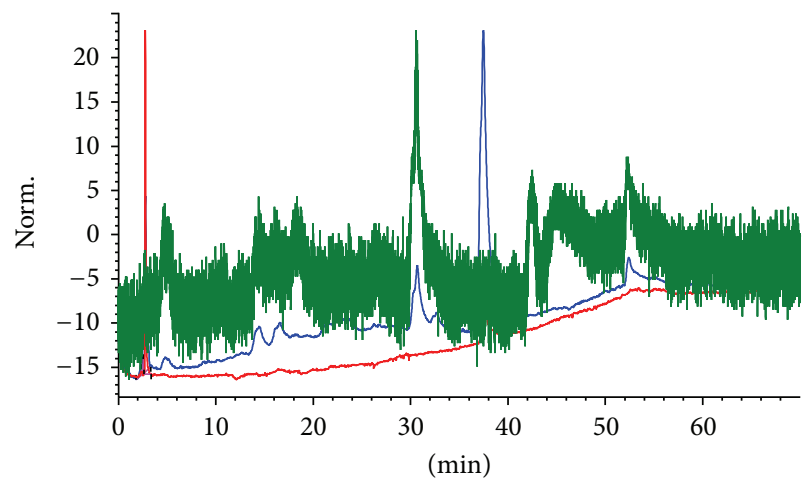

FIGURE 11: HPLC chromatogram and fluorescence peaks of lignin sulfonate solution. Concentration: $200 \mathrm{~mL}$ of $0.5 \mathrm{~g} / \mathrm{L}$, reaction time: 4 h, catalyst: $\mathrm{TiO}_{2}-\mathrm{P} 25-\mathrm{SiO}_{2}$, reaction at room temperature, presence of UV radiation, simultaneous reaction, dialysis filter, and SPE with HP-R cartridge during reaction.

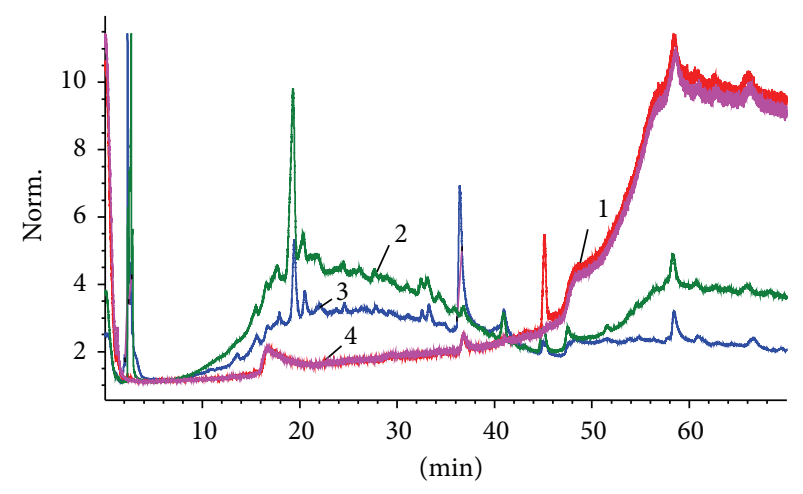

Figure 12: Fluorescence chromatogram of lignin sulfonate degradation product. Emission spectrum, $\lambda_{\mathrm{em}}: 240 \mathrm{~nm}, \lambda_{\mathrm{ex}}$ : $330 \mathrm{~nm}$, concentration: $100 \mathrm{~mL} 0.5 \mathrm{~g} / \mathrm{L}$, reaction time: $20 \mathrm{~h}$, catalyst: $\mathrm{TiOSO}_{4}-30.6 \mathrm{wt} \%$, and reaction at room temperature. (1) Absence of UV radiation and SPE with HP-R cartridge after reaction suspended in methanol. (2) Presence of UV radiation and SPE with HP-R cartridge after reaction suspended in methanol. (3) Presence of UV radiation and simultaneous SPE with HP-R cartridge during reaction. (4) Presence of UV radiation and aqueous raffinate from continuous extraction.

4.2. Fluorescence and HPLC Results. Fluorescence spectroscopy was used as a means to identify nonaliphatic component in the complex mixture of lignin degradation products. Fluorescence emission in lignin is attributed to aromatic structures such as conjugated carbonyl, biphenyl, phenylcoumarone, and stilbene groups [38, 39]. New fluorophores were detected in the time ranging from $10 \mathrm{~min}$ to around $40 \mathrm{~min}$ (Figure 12) with application of $\mathrm{TiOSO}_{4-3} 30.6 \mathrm{wt} \%$ catalyst. With the use of $\mathrm{TiO}_{2}-\mathrm{P} 25-\mathrm{SiO}_{2}$ catalyst, new fluorophores were detected as soon as $5 \mathrm{~min}$ to around $55 \mathrm{mins}$ (Figure 11).

Comparing pathway (2) and pathway (3) from Figure 12, it was observed that the fluorophores produced had similar retention times and similar peak areas. This indicates that it did not matter if extraction was done after the reaction or 
during the reaction. No peaks were observed for (1) reinforcing the necessity of UV light for lignin sulfonate degradation. The absence of peaks for (4) suggests that degradation was complete and all produced substances were adsorbed on the SPE cartridge. Moreover, tailing was observed for samples (1) and (4) that did not contain degradation products that dissolved in it.

Figure 11 depicts an HPLC and fluorescence chromatogram in which both measuring apparatus were coupled. The peak at around $2 \mathrm{~min}$ retention time arises from methanol used as eluting agent during SPE. Peaks were observed on both chromatograms suggesting the production of new substances in which there are some generated fluorescence peaks. However some fluorescence peaks appear only on the fluorescence chromatogram. Also broad peaks were found both on the HPLC and fluorescence chromatograms. During measurements (diode array detector) DAD wavelength was set at $240 \mathrm{~nm}$ and not all degradation products could be detected at this particular wavelength. In fact, one of the challenges to analyze lignin through HPLC is to set the DAD wavelength for maximum detection. An analogous scenario was observed during fluorescence in which emission wavelength was set at $240 \mathrm{~nm}$ and excitation wavelength set at $330 \mathrm{~nm}$. These difficulties arise because of the vast range of possible products arising from lignin degradation. Because of that, distinct emission decay peaks cannot be produced due to superimposition of the different fluorophores.

\section{Conclusion}

Commercial obtainable $\mathrm{TiO}_{2}-\mathrm{P} 25$ widely applied in suspension systems was effectively immobilized on sintered glass support with the aid of tetraethyl orthosilicate (TEOS) solution which acted as support material. The catalytic films synthesized had very good adherence on the sintered glass and the films retained a constant efficiency when reused after being washed with water. The coatings were considerably well distributed all over the surface of the sintered glass. Moreover, the reactor design in this work effectively degraded relatively high concentration of lignin sulfonate solutions $(500 \mathrm{mg} / \mathrm{L})$ from paper waste water.

UV-Vis spectroscopy revealed a faster transformation of the aliphatic side chains as compared to the aromatic species. Adding $\mathrm{Pt}$ as metal ion to $\mathrm{TiO}_{2}-\mathrm{P} 25-\mathrm{SiO}_{2}$ catalyst showed a negligible effect on degradation rates. The reaction rate of the catalytic systems was in the order of $\mathrm{TiO}_{2}-\mathrm{P} 25$ $\mathrm{SiO}_{2}+\mathrm{Pt} \sim \mathrm{TiO}_{2}-\mathrm{P} 25-\mathrm{SiO}_{2}>\mathrm{ZnO}+\mathrm{TiO}_{2}-\mathrm{P} 25-\mathrm{SiO}_{2}>$ $\mathrm{TiOSO}_{4}$-30.6 wt $\%$.

Peaks were observed on HPLC and fluorescence chromatograms suggesting the production of new substances and fluorophores. Through simultaneous reaction-extraction pathways applying dialysis filtration and highly porous polystyrene divinylbenzene adsorbent resin (HR-P), an attempt has been made to isolate smaller molecules produced from photocatalytic degradation.

\section{Conflict of Interests}

The authors declare that there is no conflict of interests regarding the publication of this paper.

\section{Acknowledgments}

The authors gratefully thank the Federal Ministry of Education and Research (BMBF) for funding (FKZ17N0310). The authors also thank Sappi-Ehingen AG, Robu Filterglas $\mathrm{GmbH}$, Hattert, and Evonik industries for providing materials used in this work.

\section{References}

[1] M. N. S. Kumar, A. K. Mohanty, L. Erickson, and M. Misra, "Lignin and its applications with polymers," Journal of Biobased Materials and Bioenergy, vol. 3, no. 1, pp. 1-24, 2009.

[2] N. Tantemsapya, W. Wirojanagud, and S. Sakolchai, "Removal of color, COD and lignin of pulp and paper wastewater using wood ash," Journal of Science and Technology, pp. 1-12, 2004.

[3] C. Hill, Wood Modification: Chemical, Thermal, and Other Processes, John Wiley \& Sons, Chichester, UK, 2006.

[4] D. Mantzavinos and E. Psillakis, "Enhancement of biodegradability of industrial wastewaters by chemical oxidation pretreatment," Journal of Chemical Technology and Biotechnology, vol. 79, no. 5, pp. 431-454, 2004.

[5] J. Zakzeski, P. C. A. Bruijnincx, A. L. Jongerius, and B. M. Weckhuysen, "The catalytic valorization of lignin for the production of renewable chemicals," Chemical Reviews, vol. 110, no. 6, pp. 3552-3599, 2010.

[6] C. AwungachaLekelefac, N. Busse, P. Czermak, and M. Herrenbauer, "Photocatalytic based degradation processes of lignin derivatives," in press.

[7] E. Masai, Y. Katayama, and M. Fukuda, "Genetic and biochemical investigations on bacterial catabolic pathways for ligninderived aromatic compounds," Bioscience, Biotechnology and Biochemistry, vol. 71, no. 1, pp. 1-15, 2007.

[8] E. Meux, P. Prosper, E. Masai et al., "Sphingobium sp. SYK6 LigG involved in lignin degradation is structurally and biochemically related to the glutathione transferase omega class," FEBS Letters, vol. 586, no. 22, pp. 3944-3950, 2012.

[9] N. Busse, D. Wagner, M. Kraume, and P. Czermak, "Reaction kinetics of versatile peroxidase for the degradation of lignin compounds," American Journal of Biochemistry and Biotechnology, vol. 9, no. 4, pp. 365-394, 2013.

[10] J. Rodrigues, J. Graça, and H. Pereira, "Influence of tree eccentric growth on syringyl/guaiacyl ratio in Eucalyptus globulus wood lignin assessed by analytical pyrolysis," Journal of Analytical and Applied Pyrolysis, vol. 58-59, pp. 481-489, 2001.

[11] R. Alén, E. Kuoppala, and P. Oesch, "Formation of the main degradation compound groups from wood and its components during pyrolysis," Journal of Analytical and Applied Pyrolysis, vol. 36, no. 2, pp. 137-148, 1996.

[12] K. Pan, M. Tian, Z.-H. Jiang, B. Kjartanson, and A. Chen, "Electrochemical oxidation of lignin at lead dioxide nanoparticles photoelectrodeposited on $\mathrm{TiO}_{2}$ nanotube arrays," Electrochimica Acta, vol. 60, pp. 147-153, 2012.

[13] M. G. Neumann, R. A. M. C. De Groote, and A. E. H. Machado, "Flash photolysis of lignin: part 1. Deaerated solutions 
of dioxane-lignin," Polymer Photochemistry, vol. 7, no. 5, pp. 401-407, 1986.

[14] K. P. Kringstad and S. Y. Lin, "Mechanism in the yellowing of high yield pulps by light. Structure and reactivity of free radical intermediates in the photodegradation of lignin," Tappi, vol. 53, no. 12, pp. 2296-2301, 1970.

[15] A. Castellan, N. Colombo, C. Vanucci, P. F. de Violet, and H. Bouas-Laurent, "A photochemical study of an Omethylated $\alpha$-carbonyl $\beta$-1 lignin model dimer: $1,2-\operatorname{di}\left(3^{\prime}, 4^{\prime}\right.$ dimethoxyphenyl)ethanone (deoxyveratroin)," Journal of Photochemistry and Photobiology A: Chemistry, vol. 51, no. 3, pp. 451-467, 1990.

[16] P. Mazellier, M. Sarakha, A. Rossi, and M. Bolte, “The aqueous photochemistry of 2,6-dimethylphenol. Evidence for the fragmentation of the $\alpha \mathrm{C}-\mathrm{C}$ bond," Journal of Photochemistry and Photobiology A: Chemistry, vol. 115, no. 2, pp. 117-121, 1998.

[17] J. Gierer, "Formation and involvement of superoxide (O2.-/ $\mathrm{HO} 2 \cdot)$ and hydroxyl $(\mathrm{OH} \cdot)$ radicals in TCF bleaching processes: a review," Holzforschung, vol. 51, no. 1, pp. 34-46, 1997.

[18] A. E. H. MacHado, A. M. Furuyama, S. Z. Falone, R. Ruggiero, D. D. S. Perez, and A. Castellan, "Photocatalytic degradation of lignin and lignin models, using titanium dioxide: the role of the hydroxyl radical," Chemosphere, vol. 40, no. 1, pp. 115-124, 2000.

[19] N. Serpone, "Relative photonic efficiencies and quantum yields in heterogeneous photocatalysis," Journal of Photochemistry and Photobiology A: Chemistry, vol. 104, no. 1-3, pp. 1-12, 1997.

[20] M. R. Hoffmann, S. T. Martin, W. Choi, and D. W. Bahnemann, "Environmental applications of semiconductor photocatalysis," Chemical Reviews, vol. 95, no. 1, pp. 69-96, 1995.

[21] M. Rhodes, Introduction to Particle Technology, John Wiley \& Sons, 1989.

[22] F. Benyahia and K. E. O’Neill, "Enhanced voidage correlations for packed beds of various particle shapes and sizes," Particulate Science and Technology, vol. 23, no. 2, pp. 169-177, 2005.

[23] Y.-H. Xu, H.-R. Chen, Z.-X. Zeng, and B. Lei, "Investigation on mechanism of photocatalytic activity enhancement of nanometer cerium-doped titania," Applied Surface Science, vol. 252, no. 24, pp. 8565-8570, 2006.

[24] A. Houas, H. Lachheb, M. Ksibi, E. Elaloui, C. Guillard, and J.-M. Herrmann, "Photocatalytic degradation pathway of methylene blue in water," Applied Catalysis B: Environmental, vol. 31, no. 2, pp. 145-157, 2001.

[25] V. Vuppala, M. G. Motappa, S. S. Venkata, and P. H. Sadashivaiah, "Photocatalytic degradation of methylene blue using a zinc oxide-cerium oxide catalyst," European Journal of Chemistry, vol. 3, no. 2, pp. 191-195, 2012.

[26] C. Awungacha Lekelefac, P. Czermak, and M. Herrenbauer, "Evaluation of photocatalytic active coatings on sintered glass tubes by methylene blue," International Journal of Photoenergy, vol. 2013, Article ID 614567, 9 pages, 2013.

[27] S. R. Yoganarasimhan and C. N. R. Rao, "Mechanism of crystal structure transformations. Part 3.-factors affecting the anatase-rutile transformation," Transactions of the Faraday Society, vol. 58, pp. 1579-1589, 1962.

[28] Y. Hu, H.-L. Tsai, and C.-L. Huang, "Phase transformation of precipitated $\mathrm{TiO}_{2}$ nanoparticles," Materials Science and Engineering A, vol. 344, no. 1-2, pp. 209-214, 2003.

[29] L. Tonucci, F. Coccia, M. Bressan, and N. d'Alessandro, "Mild photocatalysed and catalysed green oxidation of lignin: a useful pathway to low-molecular-weight derivatives," Waste and Biomass Valorization, vol. 3, no. 2, pp. 165-174, 2012.
[30] H. Ohnishi, M. Matsumura, H. Tsubomura, and M. Iwasaki, "Bleaching of lignin solution by a photocatalyzed reaction on semiconductor photocatalysts," Industrial and Engineering Chemistry Research, vol. 28, no. 6, pp. 719-724, 1989.

[31] A. Shende, R. Jaswal, D. Harder-Heinz, A. Menan, and R. Shende, "Intergrated photocatalytic and microbial degradation of kraft lignin," Cleantech, pp. 120-123, 2012.

[32] K. J. Laidler, Chemical Kinetics, Harper \& Row, 3rd edition, 1987.

[33] PSA Ciemat, "Platforma Solar de Almeria. Solar Photocatalysis," http://www.psa.es/webesp/areas/tsa/docs/solar_photocatalysis.pdf.

[34] K. Tanaka, R. C. R. Calanag, and T. Hisanaga, "Photocatalyzed degradation of lignin on $\mathrm{TiO}_{2}$," Journal of Molecular Catalysis A: Chemical, vol. 138, no. 2-3, pp. 287-294, 1999.

[35] H. Ohnishi, M. Matsumura, H. Tsubomura, and M. Iwasaki, "Bleaching of lignin solution by a photocatalyzed reaction on semiconductor photocatalysts," Industrial and Engineering Chemistry Research, vol. 28, no. 6, pp. 719-724, 1989.

[36] E. Portjanskaja and S. Preis, "Aqueous photocatalytic oxidation of lignin: the influence of mineral admixtures," International Journal of Photoenergy, vol. 2007, Article ID 76730, 7 pages, 2007.

[37] S. K. Kansal, M. Singh, and D. Sud, "Studies on $\mathrm{TiO}_{2} / \mathrm{ZnO}$ photocatalysed degradation of lignin," Journal of Hazardous Materials, vol. 153, no. 1-2, pp. 412-417, 2008.

[38] A. Castellan, H. Choudhury, R. Stephen Davidson, and S. Grelier, "Comparative study of stone-ground wood pulp and native wood 3. Application of fluorescence spectroscopy to a study of the weathering of stone-ground pulp and native wood," Journal of Photochemistry and Photobiology A: Chemistry, vol. 81, no. 2, pp. 123-130, 1994.

[39] B. Albinsson, S. Li, K. Lundquist, and R. Stomberg, "The origin of lignin fluorescence," Journal of Molecular Structure, vol. 508, no. 1-3, pp. 19-27, 1999.

[40] J. Zakzeski, P. C. A. Bruijnincx, A. L. Jongerius, and B. M. Weckhuysen, "The catalytic valorization of lignin for the production of renewable chemicals," Chemical Reviews, vol. 110, no. 6, pp. 3552-3599, 2010. 

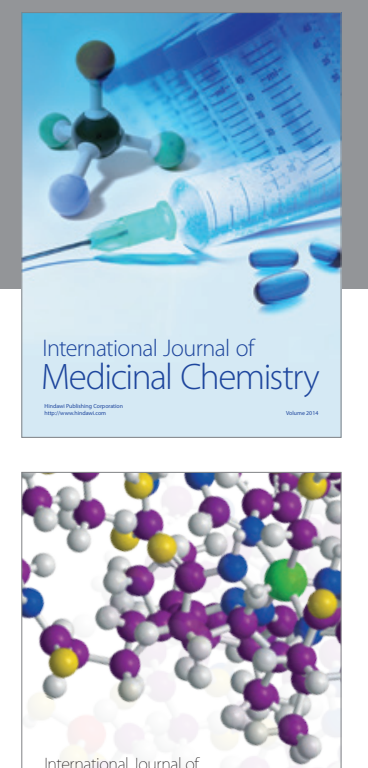

\section{Carbohydrate} Chemistry

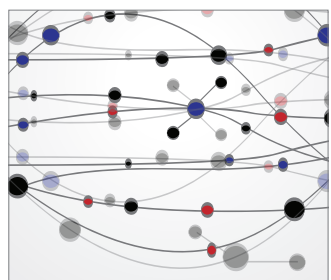

The Scientific World Journal
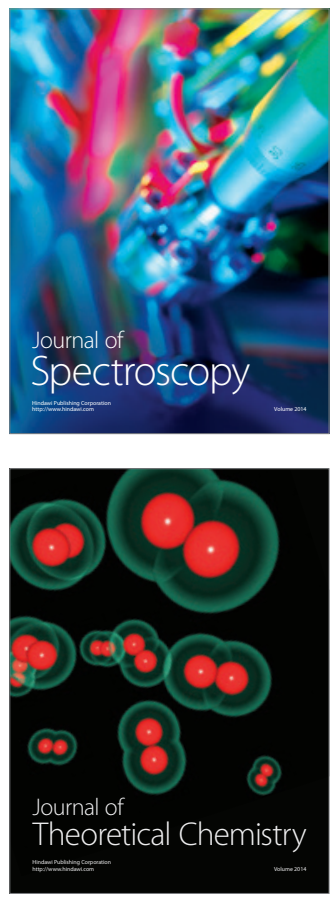
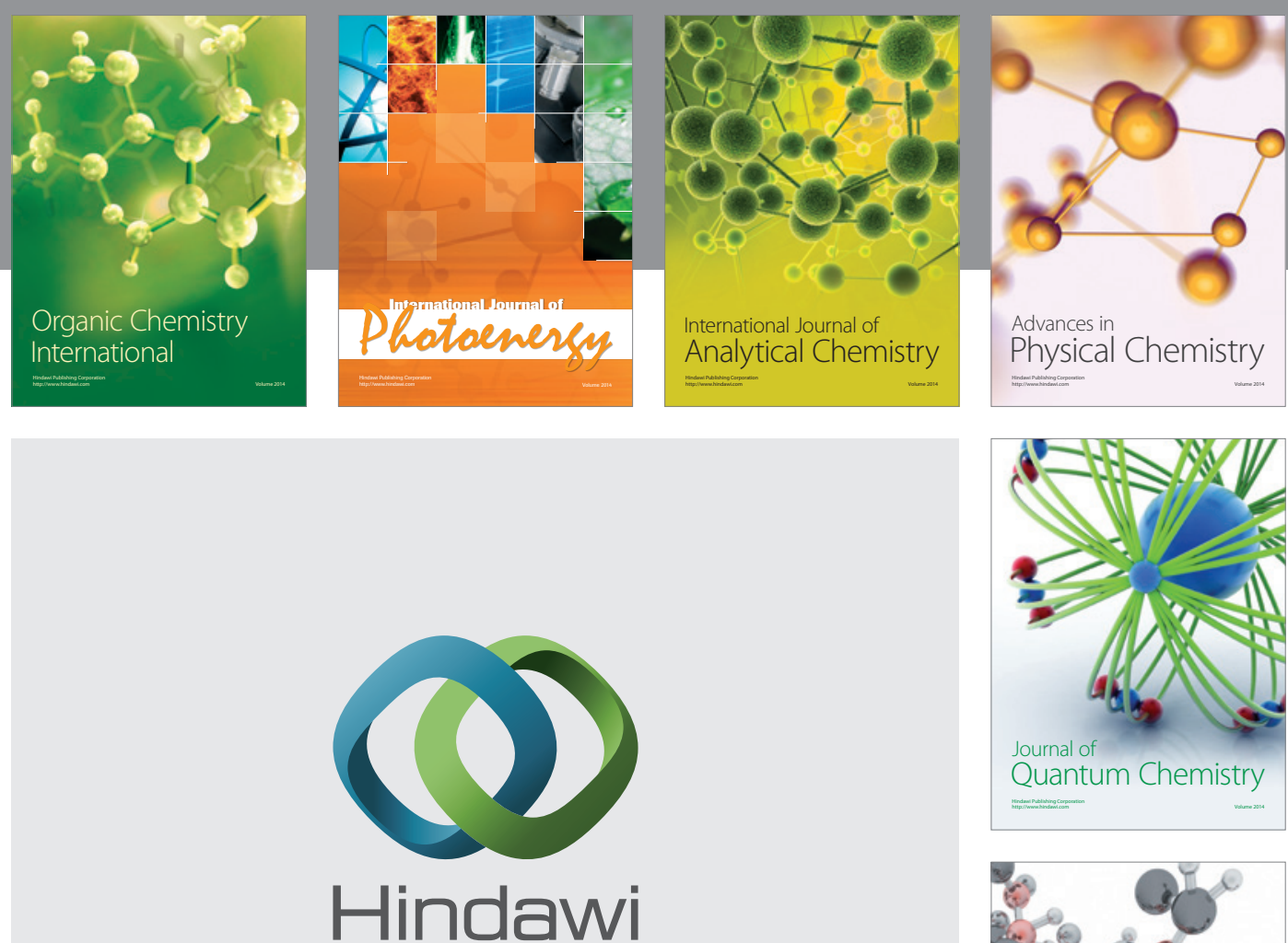

Submit your manuscripts at

http://www.hindawi.com

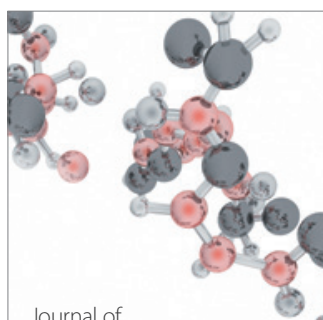

Analytical Methods

in Chemistry

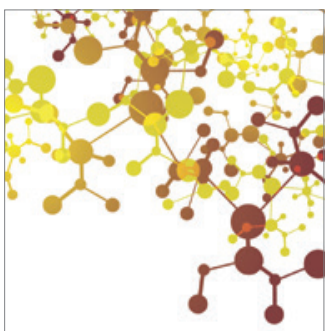

Journal of

Applied Chemistry

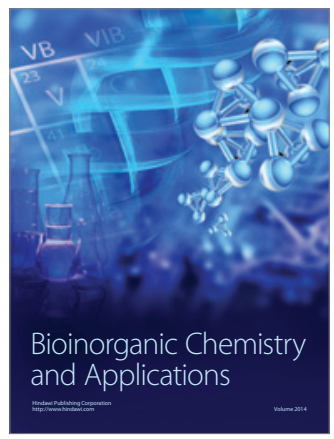

Inorganic Chemistry
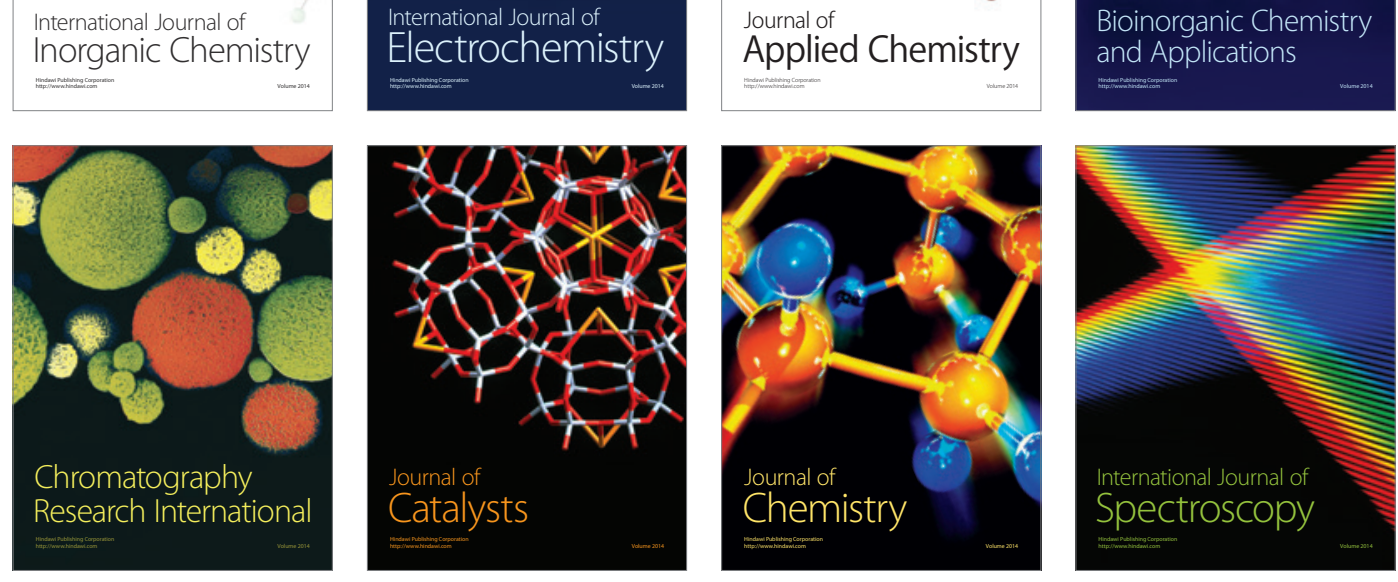